\title{
The Relationship between Endogenous Factors and Contact Dermatitis on Electroplating Workers in Durungbanjar
}

\section{Hubungan antara Faktor Endogen dengan Dermatitis Kontak pada Pekerja Electroplating di Durungbanjar}

\author{
Yasmien Alvira ${ }^{1}$, Danang Setia Budi ${ }^{2}$ \\ ${ }^{1}$ Department of Occupational Safety and Health, Faculty of Public Health, Universitas Airlangga \\ Campus C Mulyorejo, Surabaya, East Java, 60115, Indonesia \\ ${ }^{2} \mathrm{CV}$. Setia Sari \\ Sukolilo, Surabaya, East Java, 60111, Indonesia
}

\begin{abstract}
Introduction: Occupational contact dermatitis can be interpreted as a health problem on the skin caused by exogenous and endogenous factors related to work. Electroplating is one of high-risk jobs that caused occupational contact dermatitis because of direct contact with chemicals during working. In addition, contact dermatitis is also affected by individual factors of each worker. This research purpose was to identify the relationship among endogenous factors and the occupational contact dermatitis case in metal coating workers in home industry. Method: The research design used was observational with a cross sectional approach. The total population was used as the sampling technique in this study with a total of 28 workers from two metal coating industries in Durungbanjar Village consisting 13 workers from CV. M and 15 workers from CV. N. The data were obtained from the survey, sighting, and medical record notes. Variables from the study included age, working period, history of illness, and personal hygiene. The data were processed using the coefficient contingency test. Result: There were $64.3 \%$ of electroplating workers experienced contact dermatitis. The age aspect has a weak relationship $(c=0.295)$, the working period element has a weak relationship $(c=0.298)$, the disease history factor has a weak relationship $(\mathrm{c}=0.352)$ and the individual hygiene factor has a strong relationship $(\mathrm{c}=0.547)$. Conclusion: The endogenous factors including age, working period, history of disease, and personal hygiene affect contact dermatitis case. There is a strong relationship between personal hygiene and contact dermatitis cases in metal coating workers. The worse personal hygiene of the workers, the higher risk of workers experiencing contact dermatitis. Age, working period, and history of disease had weak relationship with contact dermatitis case.
\end{abstract}

Keywords: contact dermatitis, endogenous factors, metal coatings

\section{ABSTRAK}

Pendahuluan: Dermatitis kontak akibat kerja memiliki arti sebagai gangguan kesehatan pada kulit yang timbul karena pengaruh adanya faktor eksogen dan faktor endogen yang berhubungan dengan pekerjaan. Electroplating termasuk salah satu pekerjaan berisiko tinggi yang menyebabkan timbulnya dermatitis kontak akibat kerja karena saat bekerja bersentuhan langsung dengan bahan kimia. Selain itu dermatitis kontak juga dipengaruhi faktor individu dari masingmasing pekerja. Tujuan dari penelitian ini adalah untuk melihat hubungan antara faktor endogen dengan kasus dermatitis kontak akibat kerja pada pekerja pelapis logam home idustri. Metode: Desain penelitian menggunakan observasional dengan pendekatan cross sectional. Total populasi menjadi teknik sampel pada penelitian ini dengan jumlah 28 pekerja, yang berasal dari 2 industri pelapisan logam di Desa Durungbanjar dengan masing-masing pekerja berjumlah 13 pekerja dari CV. M dan 15 pekerja dari CV. N. Data didapatkan dari kuesioner, observasi, dan lembar rekam medis. Variabel penelitian ini adalah usia, masa kerja, riwayat penyakit, dan personal higiene. Data dianalisis menggunakan uji kontigensi koefisien. Hasil: Terdapat 64,3\% pekerja electroplating di Desa Durungbanjar mengalami dermatitis kontak. Faktor usia memiliki hubungan yang lemah $(c=0,295)$, faktor masa kerja memiliki hubungan yang lemah $(c=0,298)$, faktor riwayat penyakit memiliki hubungan yang lemah $(c=0,352)$ dan faktor personal higiene memiliki hubungan yang kuat $(c=0,547)$. Simpulan: Faktor endogen yang meliputi usia, masa kerja, riwayat penyakit, dan personal higiene berpengaruh terhadap kejadian dermatitis kontak. Terdapat korelasi yang kuat antara personal higiene terhadap kasus dermatitis kontak pada pekerja pelapis logam. Semakin buruk personal higiene pekerja, maka semakin tinggi risiko pekerja mengalami dermatitis kontak.. Usia, masa kerja, dan riwayat penyakit memiliki hubungan yang lemah dengan kejadian dermatitis kontak.

Kata kunci: dermatitis kontak, factor endogen, pelapis logam

(C2020 IJOSH All right reserved. Open access under CC BY NC-SA license doi: 10.20473/ijosh.v9i3.2020.258-268 Received July 10, 2020, received in revised form September 07, 2020, Accepted October 31, 2020, Published: November 2020 


\section{Corresponding Author:}

Yasmien Alvira

Email: yasmien.alvira-2016@fkm.unair.ac.id

Telephone : +6281333484163

\section{INTRODUCTION}

The modern way of manufacturing handicrafts, motorized vehicle components, and factory equipment includes metal coating process. Metal coating is an attempt made to coat a metal surface using chemicals in the form of zinc, copper, nickel, chromium which aims to increase the microstructure, durability physical properties of the object (Fasya, 2018).

Electroplating process is classified as a finishing process (metal finishing). Electroplating is the process of coating metal by utilizing electric currents and certain chemical compounds to move the metal particles of the coating to the material to be coated. The purpose of the electroplating process is to improve the technical properties of a metal, protect the metal from corrosion, and enhance the appearance of the metal. However, there are dangerous chemicals in this process which contact the workers, those are chromium and nickel. When Nickel as a dangerous chemical contacta with the skin, it can cause contact dermatitis (Berniyanti, 2018).

The percentage of occupational dermatitis reached $50-60 \%$ of the number of occupational and occupational related diseases (Suma'mur, 2014). As stated by the European Association of Occupational Health and Safety Experts, skin diseases placed second as the most occupational diseases in Europe. According to surveillance data in America, as much as $80 \%$ of occupational dermatoses are contact dermatitis (Hastuty, 2018). According to data from the Association of Indonesian Skin Specialists in 2009 , contact dermatitis cases have reached $90 \%$ of the total number of skin diseases. East Java Health Office surveillance results in the third quarter of 2013 found that contact dermatitis was ranked in the top 6 out of 10 with a total of 18,702 patients.

Contact dermatitis is a skin disease caused by a substance attached to the skin. It is divided into two; irritant contact dermatitis and allergic dermatitis, both of which can be acute or chronic (Stateschu, 2011). All skin disorders caused by work are called occupational dermatitis (Suma'mur, 2014). Nearly three-quarters of total cases of occupational contact dermatitis are primary irritant contact dermatitis (Hastuty, 2018).
There are two factors that can cause dermatitis, i.e exogenous and endogenous factors. Exogenous factors that can cause dermatitis include exposure to chemicals, temperature and humidity (Murlistyarini and Prawitasari, 2018). Endogenous factors that can cause dermatitis include contact duration and individual characteristics such as age, race, gender, and history of skin diseases. Another endogenous factor that causes dermatitis is personal hygiene (Rinawati and Wulandari, 2020).

According to Suryani (2011), the related factors of contact dermatitis in the processing and fulfillment workers of PT. Cosmar Indonesia found that the average worker with dermatitis was $<25$ years old. Research by Hamzah (2012) stated that workers suffering from dermatitis were dominated by workers with a working period of $<1$ year $(66.7 \%)$. Research by Alifariki et al (2019) also stated that workers with a history of illness or allergies have a greater risk for contact dermatitis. Pursuant to Prasetyo (2014), a factor related to contact dermatitis case is hand washing. Individual hygiene is generally described by hand washing behavior. This aims to avert the spread of biological agents, decrease the exposure to contamination and chemicals so as to avoid allergies to the skin and sensitivity to chemicals. Therefore, this study aimed to know the relationship between the age, working period, history of illness, individual hygiene and contact dermatitis case.

Metal industry is one of the potential possessed by Sidoarjo District. Durungbanjar Village, located in Candi Subdistrict, Sidoarjo Regency, has two metal plating $\mathrm{CV}$. $\mathrm{M}$ and $\mathrm{CV}$. $\mathrm{N}$ home industries. The metal coating home industry has 15 and 13 workers respectively. According to the observations, the number of workers with contact dermatitis in the home industry was more than half of the population. Based on this background, this study analyzed the contact dermatitis case and its causal factors aiming to analyze the factors associated with contact dermatitis in the home industry. These elements were age, working period, history of disease, and individual hygiene.

\section{METHODS}

This was an observational study. This study used a cross-sectional approach since the measurement of the dependent variable and the independent variable was conducted once at the same time. According to data analysis, this research was classified as observational research that aimed 
to describe the relationship of factors considered to affect the contact dermatitis case on workers in the electroplating home industry in Durungbanjar Village. This study was carries out in March 2019. This study was avowed by the Institutional Ethics Council of the Faculty of Public Health, Universitas Airlangga with recorded number of 105/ EA/KEPK/2019. The target in this study were all workers in the electroplating industryof CV. M and $\mathrm{CV}$. N which is located in Durungbanjar Village, Candi Sub-District, Sidoarjo District. This study used total population as the sample amounting to 28 workers, consisting of 13 people from CV. M and 15 people from $\mathrm{CV}$. N.

Occupational contact dermatitis was the dependent variable in this research. Diagnosis to determine contact dermatitis case caused by work was done by a doctor who has been certified as a doctor of Environmental Health and Safety. Age, working period, history of illness, and individual hygiene were the independent variables in this study. This study used data taken directly through the results of questionnaire sheets, interviews, observations and medical records from the doctors. Univariate analysis was used to determine the description of each variable presented in tabular and percentage data. Bivariate analysis was used to determine whether there was a relationship among the dependent variable and the independent variable. Chi square test with $95 \%$ confidence level was used to conduct bivariate analysis. In addition, the data was also analyzed through coefficient contingency test to set the strength of the relationship among the variables that was interpreted using the relationship coefficient containing 5 interpretation relationship values.

\section{RESULT}

Two electroplating home industries which are $\mathrm{CV} . \mathrm{M}$ and CV. N, become the research location. Both are in the Village of Durungbanjar, Candi SubDistrict, Sidoarjo District, East Java. Electroplating industry in CV. M has 13 workers, while the electroplating industry at CV. N has 15 workers. The electroplating industried already have a written business permit so it can be considered as legal business.

Electroplating Industry CV. M started the production process in 2001 and operates every day except Sunday. Electroplating Industry CV. N started its production process in 2005 and have the same working day as CV. M. All of these electroplating industries carry out metal coating production based on consumer demand or order. The resulting production includes metal chairs, spare parts, and motor vehicles.

Metal coatings use chemicals such as nickel, sulfuric acid and chromium. Nickel and chromium act to coat the metal pieces, while the acidification and cleaning of metals uses sulfuric acid. The chemicals used in coating these metals can cause various serious health problems. However, metal coating workers do not to take these health problems seriously.

Metal coating industries of $\mathrm{CV} . \mathrm{M}$ and $\mathrm{CV}$. $\mathrm{N}$ have the same coating process. This consists of the process of polishing, acidifying, rinsing, metal coating, and drying. The metal coating process carried out by electroplating home industrylies can be seen in Figure 1.

Electroplating Home Industry of CV. M has 13 workers and all are male. The workers are divided into several work processes. There are 3 workers in the polishing process, 3 workers in the acidification process, 6 workers in the coating process and 2 workers in the rinsing process. At the electroplating home industry of CV. N, there are 15 workers and all workers are male. The workers are also divided

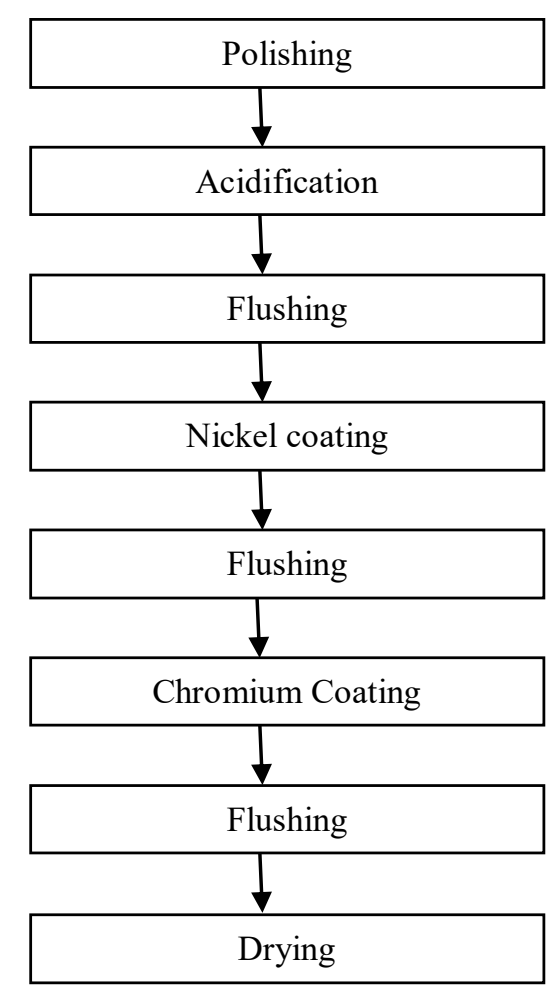

Figure 1. Metal Coating Process in the Electroplating Home Industry 
based on the work process. There were 4 workers in the polishing process, 2 workers in the acidification process, 4 workers in the coating process, and the rest works in the flushing process.

The polishing process is carried out on the surface of the object using a grinding tool such as grinding and sandpaper which aims to smooth the object before the coating process. After the polishing process, the acidification process is carried out. The workpiece will be immersed in a hydrochloric acid solution aimed to remove the rust. The next process is the flushing process. It aims to remove acidification liquid that sticks to the workpiece. The nickel coating process is the first coating process before the second coating process by using chromium. The coating process is done by dipping the workpiece/metal in a tub containing chemical nickel and chromium in a certain period of time by using a hook that has been electrified. The drying process is the last process. The produced objects/ metals will be dried in the sun to dry the chemicals attached

The results of the distribution of workers with contact dermatitis at the Electroplating Home Industry in Durungbanjar Village is displayed in

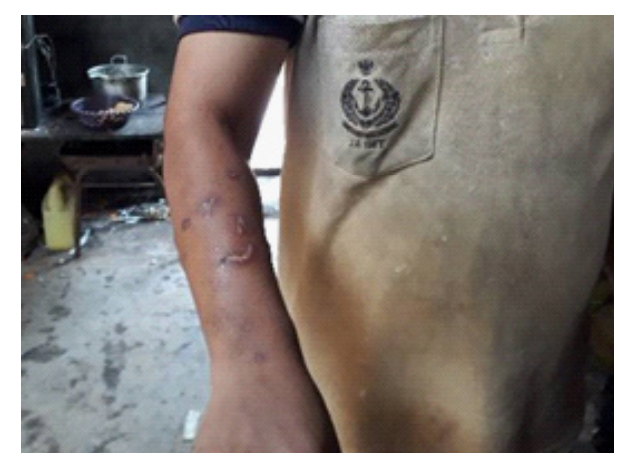

Figure 2. Contact Dermatitis in Electroplating Home Industry workers in Durungbanjar Village

Table 1. The Distribution of Contact Dermatitis Cases on Electroplating Home Industry workers in Durungbanjar Village, March 2019

\begin{tabular}{ccc}
\hline \multirow{2}{*}{ Contact Dermatitis Events } & \multicolumn{2}{c}{ Total } \\
\cline { 2 - 3 } & $\mathbf{N}$ & $\mathbf{\%}$ \\
\hline Contact dermatitis & 10 & 64.3 \\
Non-Contact dermatitis & 18 & 35.7 \\
\hline Total & 28 & 100 \\
\hline
\end{tabular}

Table 1. Complaints of skin disorders which are the indicators of someone diagnosed with contact dermatitis occur in the worker's body section including chest and stomach skin, leg, hands, and back skin.

The percentage of workers who experienced contact dermatitis at Electroplating Home Industry in Durungbanjar Village, Candi Sub-District, Sidoarjo District was $64.3 \%$ with a total of 18 workers. Most contact dermatitis occurred in the hands of workers. The percentage of workers who were not diagnosed with contact dermatitis was $35.7 \%$ (10 people). Endogenous factors which include age, working period, experience of illness, and individual hygiene can affect the onset of contact dermatitis.

Age

Based on table 2, 32.1\% of workers aged over 45 years, $25 \%$ of workers aged of $17-25$ years and $21.4 \%$ aged $26-35$ years and $36-45$ years, respectively. The average age of electroplating home industry workers in Durungbanjar Village was $39.28 \%$ with the age range for the youngest worker being 21 years old and the oldest worker aged 67 years old.

\section{Working Period}

The working periods variable was divided into 2 categories, those are working period of less than 6 years and more than 6 years. Based on table 3 , $50 \%$ of the Electroplating Home Industry workers in Durungbanjar Village have been working there for more than 6 years. Workers whose working period is less than 6 years have the same percentage of $50 \%$. The average working periods of all Electroplating Home Industry workers is 6.43 (6 years 5 months) and starts from workers who work for 0 year to 18 years.

Table 2. Age Distribution of Electroplating Home Industry Workers in Durungbanjar Village, March 2019

\begin{tabular}{ccc}
\hline Age & Frequency $(\mathbf{n})$ & Percentage $\mathbf{( \% )}$ \\
\hline 17-25 Years Old & 7 & 25 \\
26-35 Years Old & 6 & 21.4 \\
36-45 Years Old & 6 & 21.4 \\
More than 45 & 9 & 32.1 \\
Years Old & & \\
\hline Total & 28 & 100 \\
\hline
\end{tabular}




\section{History of Disease}

The distribution of patient's disease history obtained from the answers to the questionnaire asked by the researcher's accompanied by doctor. Based on table 4, about 53.6.\% of Electroplating Home industry workers in Durungbanjar Village have experienced skin diseases and $46.4 \%$ of workers have no history of skin diseases. Most of the skin diseases suffered by workers in the form of phlegm, itching, edema, and others.

Table 3. The Distribution of Working periods of Electroplating Home Industry Workers in Durungbanjar Village, March 2019

\begin{tabular}{ccc}
\hline Working period & Frequency $(\mathbf{n})$ & Percentage $\mathbf{( \% )}$ \\
\hline$\leq 6$ Years & 14 & 50 \\
$>6$ Years & 14 & 50 \\
\hline Total & 28 & 100 \\
\hline
\end{tabular}

Table 4. The distribution of Disease History among Electroplating Home Industry Workers in Durungbanjar Village, March 2019

\begin{tabular}{ccc}
\hline History of Skin Disease & $\begin{array}{c}\text { Frequency } \\
(\mathbf{n})\end{array}$ & $\begin{array}{c}\text { Percentage } \\
(\mathbf{\%})\end{array}$ \\
\hline History of Skin Disease & 15 & 53.6 \\
No history of skin disease & 13 & 46.4 \\
\hline Total & 28 & 100 \\
\hline
\end{tabular}

\section{Personal Higiene}

Personal hygiene is generally described by hand washing behavior because it can be done by everyone easily. Other personal hygiene can be described through the cleanliness of work clothes. In addition to these two things, the cleanliness of hand nails must also be considered to keep it clean and short. Based on table 5, workers who had good or bad personal hygiene had the same percentage, which was $50 \%$, respectively. Most of the Electroplating Home Industry workers in Durungbanjar Village rarely cut their nails regularly and did not change and cleaned their working clothes regularly.

\section{DISCUSSION}

Electroplating is defined as a series of deposition processes by putting a thin layer to the surface of a metal that are commonly done using chemical reactions and electrolyte liquids where

Table 5. The Distribution of Personal Hygiene of Electroplating Home Industry Workers in Durungbanjar Village, March 2019

\begin{tabular}{ccc}
\hline Personal Higiene & Frequency (n) & Percentage (\%) \\
\hline Good & 14 & 50 \\
Poor & 14 & 50 \\
\hline Total & 28 & 100 \\
\hline
\end{tabular}

Table 6. The Relationship of Age, Working period, Disease History, and Personal Hygiene with Contact Dermatitis in Electroplating Home Industry Workers in Durungbanjar Village, March 2019

\begin{tabular}{|c|c|c|c|c|c|c|c|c|}
\hline \multirow{3}{*}{ Variable } & \multicolumn{4}{|c|}{ Contact dermatitis events } & \multirow{2}{*}{\multicolumn{2}{|c|}{ Total }} & \multirow{3}{*}{$P$ value } & \multirow{3}{*}{$\begin{array}{c}\text { Contingency } \\
\text { Coefficient }\end{array}$} \\
\hline & \multicolumn{2}{|c|}{ Dermatitis } & \multicolumn{2}{|c|}{ Non dermatitis } & & & & \\
\hline & $\mathbf{n}$ & $\%$ & n & $\%$ & $\mathbf{N}$ & $\%$ & & \\
\hline \multicolumn{9}{|l|}{ Age } \\
\hline 17-25 Years Old & 5 & 27.8 & 2 & 20 & 7 & 25 & & \\
\hline 26-35 Years Old & 5 & 27.8 & 1 & 10 & 6 & 21.4 & 0.447 & 0.295 \\
\hline 36-45 Years Old & 4 & 22.2 & 2 & 20 & 6 & 21.4 & & \\
\hline More than 45 Years Old & 4 & 22.2 & 5 & 50 & 9 & 32.2 & & \\
\hline \multicolumn{9}{|l|}{ Working period } \\
\hline$\leq 6$ Years & 11 & 61.1 & 3 & 30 & 14 & 50 & 0.237 & 0.298 \\
\hline$>6$ Years & 7 & 38.9 & 7 & 70 & 14 & 50 & & \\
\hline \multicolumn{9}{|l|}{ Disease History } \\
\hline Yes & 12 & 66.7 & 3 & 30 & 15 & 53.6 & 0.114 & 0.352 \\
\hline No & 6 & 33.3 & 7 & 70 & 13 & 46.4 & & \\
\hline \multicolumn{9}{|l|}{ Personal Higiene } \\
\hline Good & 6 & 33.3 & 8 & 80 & 14 & 50 & 0.049 & 0.547 \\
\hline Poor & 12 & 66.7 & 2 & 20 & 14 & 50 & & \\
\hline
\end{tabular}


the object is expected to be improved in terms of its microstructure, durability and physical properties (Fasya, 2018). Generally, the result of electroplating is in the form of coloring the workpiece aiming to prevent corrosion and give aesthetic value to the metal. Chemicals that are often used in several work processes in the electroplating industry are nickel and chromium. The main function of nickel is as a catalyst. In addition, it also functions for textile coloring and printing, coatings, ceramic dyes, metal alloys to resist corrosion and chemical reagents (Soedirman and Suma'mur, 2014). Nickel has acidic properties which are very corrosive to the skin. If sensitive skin comes in contact with nickel directly and continuously, it can cause ulcers. It can also be affected if someone has a history of allergies (Hernita, 2011). Exposure to chromium in the metal coating process can have health effects on workers, especially those involved in the metal coating process (Fasya, 2018). The effect of chromium oxide exposure to the skin can cause irritation, allergic, and ulcers (International Labour Organization, 2015).

The results showed that 10 out of 28 workers had contact dermatitis and the rest did not have. The contact dermatitis case is commonly found in the coating and rinsing section workers because in that process workers experience direct contact with irritant chemicals. Symptoms that are commonly felt by workers are itching and heat. These symptoms are felt when newcomers workers do the work and never been in contact with nickel or chromium. Aside from feeling itchy and hot, workers also experience chapped and scaly skin on upper body parts such as the arms, hands and some parts of the abdomen. Most of the workers assume that this is normal and do not know that those are the sign that they have been experiencing contact dermatitis due to work. This is also due to the absence of routine health checks and assumption that the symptoms they experienced are normal and felt to be mild. Contact dermatitis is a skin disease characterized by inflammation arising from responses to exogenous and endogenous factors (Murlistyarini and Prawitasari, 2018). Occupational contact dermatitis generally occurs on the hands. Occupational dermatitis has reached a percentage of about 50$60 \%$ of all occupational diseases (Suma'mur, 2014). In addition to exogenous factors, contact dermatitis can be caused by endogenous factors which include age, working period, history of illness, and personal hygiene (Suryani, 2011; Hamzah, 2012; Prasetyo, 2014).

\section{Age}

Age is one of the factors that affects the susceptibility of workers to contact dermatitis. Skin conditions will degenerate as a person ages. So the skin will become drier because it loses the fat layer above it and makes it easier for chemicals to infect the skin. This condition makes the skin more prone to dermatitis.

It can be considered that workers in older age tend to have a greater level of risk than workers who are younger. However, in fact, based on the results of research at the Electroplating Home Industry in Durungbanjar Village, younger workers are more likely to get dermatitis. This can occur because younger workers have excellent physical conditions so they tend to ignore safety while working. Research from Lestari and Utomo (2007) is in line with this statement stating that most of the workers at PT. Inti Pantja Press who experienced dermatitis were younger workers who were aged younger 30 years.

\section{Working period}

The working period has an important role in seeing the length of time a person has been exposed to various sources of disease that can lead to complaints of skin disorders. The working period can be defined as the time the worker begins to be exposed to possible sources that can cause complaints of skin disorders until the time of the study (Widianingsih and Basri, 2017). Someone's risk of being exposed to hazards arising from the work environment will be even greater if the worker has a long working period (Suma'mur, 2014).

The results of research on Electroplating Home industry workers in Durungbanjar Village showed balanced results between workers with a working period of $\leq 6$ years and $>6$ years. According to Rinawati and Wulandari (2020), a working period has an effect on contact dermatitis case. This is in line with Pradananingrum et al (2018) research which stated that the majority of workers who experienced contact dermatitis had a long working period $(82.5 \%)$.

\section{History of Disease}

The results showed that most of the electroplating home industry workers in Durungbanjar Village had a history of previous illnesses. The skin diseases suffered by workers were generally in the form of acne, tinea versicolor, 
itching, edema and others. Workers who have experienced skin diseases have previously been treated with anti-itching and inflammatory drugs, ointments as well as several topical and oral medications that were obtained from doctors or purchased through pharmacies.

According to Djuanda (2010), workers with a history or were suffering from dermatitis which are not caused by work are more susceptible to occupational dermatitis. This is because the skin protection has decreased due to the previous experience. The thinning of the skin layer, oil glands and sweat as well as changes in skin $\mathrm{pH}$ increase the susceptibility of workers to exposure resulting in the emergence of occupational skin diseases. A history of skin diseases suffered by workers can also increase the sensitivity of workers' skin to chemical exposure. When experiencing inflammation due to chemicals, the skin will be easily irritated and more susceptible to dermatitis (Suryani, 2011). Workers with a history of illness or allergies have a higher susceptibility to suffer contact dermatitis than workers who have never had a history of illness or allergies (Putri et al, 2017).

\section{Personal Hygiene}

The results of research on Electroplating home industry workers in Durungbanjar Village showed balanced results between workers who had good and bad personal hygiene. The company did not have specific regulations for maintaining personal hygiene at work. So that there were workers who did not pay attention to their personal hygiene.

One effort to prevent skin diseases is personal hygiene (Dhera and Fielrantika, 2017). Personal hygiene factors are affected by the existing cleaning facilities, cleaning quality and awareness of each worker to utilize existing cleaning facilities. Hand washing is an illustration of individual cleanliness because it is the most easily done by everyone. It is very important in maintaining personal hygiene because it is useful in preventing the spread of biological agents, reducing exposure to contamination and chemicals as good efforts to avoid skin allergies and sensitivity to chemicals.

In addition to washing hands, other hygiene that also needs attention is the cleanliness of clothing. Chemicals that are still attached to work clothes should be routinely cleaned. If their work apparel that have been exposed to chemicals is not routinely cleaned, workers will be at risk of skin inflammation. According to Sarfiah et al (2016), work clothes should be cleaned routinely at least washed before reuse or washed after one use.

In addition to hand washing behavior and cleanliness of work clothes, workers in electroplating industry must also pay attention to the cleanliness of hand nails. Nails cut should be done so that the nails remain short and clean. Based on research carry out by Miaratiska and Azizah (2015), there were 20\% of workers who had long nails experiencing skin health problems. Long left nails will cause an infection if there is friction with the skin so that exposure will be more easily in entering the body.

\section{The Relationship between Age and Contact Dermatitis at Electroplating Home Industry in Durungbanjar Village}

Based on table 3 , workers within the age range 17-25 years and 26-35 years have the same frequency of contact dermatitis case (27.8\%). According to Ernasari (2012), younger workers have a greater degree of vulnerability to contact dermatitis due to negligence at work and environments with high humidity and high heat. In addition, young workers are also considered to have low skills.

The level of relationship test between the two variables showed a weak relationship between age and contact dermatitis case $(c=0.295)$. This study result is the same as research conducted by Rosanti et al (2018) showing no obvious relationship between the age and contact dermatitis case. This possibility may occur because the study used a cross-sectional design that is still weak in analyzing cause and effect relationships, especially for longterm consequences such as age. This study is also related to the study conducted by Hamzah (2012) which showed no significant relationship between age and contact dermatitis case.

Dermatitis can affect all ages if the context of the contact dermatitis is related to age. Therefore, age is not one of the main cause elements for contact dermatitis (Hamzah, 2012). This study conclusion is also showed that contact dermatitis case was more common among younger workers compared with older workers.

The Relationship between Working period and Contact Dermatitis at Electroplating Home Industry in Durungbanjar Village

Working period was determined from the duration of work in units of years. The working period was obtained from the results of the 
questionnaire. The outcome of the contingency coefficient indicates that there was a weak relationship between the working period (year) and contact dermatitis case in electroplating home industry workers $(\mathrm{c}=0.298)$. This is similar to the research conducted by Rahma et al (2017) which showed that no significant relationship between working period and contact dermatitis case. This research is also similar to research performed by Rachmasari (2012) stating that there was no meaningful relationship between working period and contact dermatitis case on metal plating workers.

The average working period was 6 years. The outcome of this study indicated that there were workers who sufferred from contact dermatitis with working period of less than 6 years. One of the workers suffering from contact dermatitis is a worker with a working period of 2 years. Some workers who have worked for a long time were considered to have good skin thickness so they did not suffer from contact dermatitis. There may be other factors that cause workers to experience contact dermatitis with a minimum service period. Workers who are just starting out compared to workers who have long working period were considered to have differences in terms of knowledge and work skills. In addition, based on the outcome of interviews with the business owners, workers who have been worked for more than 6 years on average have moved parts and work on dry work parts such as cleaning and polishing that the workers has stopped working in parts that have direct contact with chemicals. Job type factor is considered to be another factor that affects the contact dermatitis case. In conclusion, working period is not among the main factors causing metal coating workers to suffer from contact dermatitis. Workers with new and old working period remain at risk of developing contact dermatitis due to work (Paendong et al, 2017).

\section{The Relationship between History of Disease and Contact Dermatitis at Electroplating Home Industry in Durungbanjar Village}

The results of the bivariate analysis in this study showed that there was no significant relationship between the history of skin diseases and contact dermatitis case in Electroplating workers in Durungbanjar Village $(c=0.352)$. The results of this study are in line with research performed by Chafidz and Dwiyanti (2018) which stated that there was no relationship between the history of the disease with contact dermatitis case in workers exposed to chemicals. This study is also in line with the study conducted by Alifariki et al (2019) which showed no relationship between the history of skin disease and contact dermatitis case.

The study also showed that among all workers suffering from contact dermatitis, $33.3 \%$ of workers had contact dermatitis even though they had no previous skin disease history. It can be concluded that all workers who had or did not have a history of skin diseases have the potential to suffer from contact dermatitis because all workers, especially those working in the coating and rinsing area, have direct contact with chemicals while working. In general, the cause of contact dermatitis is exposure to chemicals on the skin. The skin will experience damage due to irritation and inflammation caused by chemical substances (Marks and Miller, 2017).

\section{The Relationship between Personal Hygiene and Contact Dermatitis in the Electroplating Home Industry in Durungbanjar Village}

Based on table 3, 66.7\% of workers sufferred from contact dermatitis and had poor personal hygiene. There were $33.3 \%$ of workers suffered from contact dermatitis and had great individual hygiene. The output of the bivariate analysis indicated that there was a significant relationship among individual hygiene and contact dermatitis case among electroplating home industry workers in Durungbanjar Village. The strong relationship test among the variables likewise indicated a coefficient contingency value of 0.547 which means that there was a firm relationship among personal hygiene and contact dermatitis case. This study is equal with research conducted by Putri (2019) stating that there was a strong relationship between personal hygiene and the case of occupational contact dermatitis. The risk of contact dermatitis is increased if a person's personal hygiene is poor. Poor personal hygiene facilitates the development of germs and bacteria on the skin. This study is also similar to the research conducted by Wardani et al (2018) which indicated that personal hygiene was associated with contact dermatitis case. The results of this study also stated that workers with poor personal hygiene had a 9 times greater risk of developing contact dermatitis opposed to workers with great individual hygiene.

Data on personal hygiene in this study were obtained from observations and questions and answers through questions in the questionnaire. Most of the workers had poor personal hygiene. The average worker washed his hands before starting 
and after doing work. However, hand washing is usually done in a rinse bath mixed with a metal rinse bath. This is certainly not in accordance with the concept of good hand washing because it did not use running water. In addition, the electroplating home industry $\mathrm{CV}$. $\mathrm{M}$ and $\mathrm{CV}$. $\mathrm{N}$ did not provide a special hand washing area that was equipped with hand washing soap so workers only washed their hands using a dab of soap. Inappropriate exposure to soap aggravates the skin condition of workers so that it can increase the risk of contact dermatitis (Frosch, 2011). Proper hand washing before doing work is useful for eliminating germs and bacteria that stick to the skin so it does not get carried away when workers do the work process. Washing hands after doing work is useful to neutralize the $\mathrm{pH}$ of chemicals attached to the hands (Fithri et al, 2019).

Based on the observations, some workers still re-wore their work clothes without washing first. This can increase the risk for workers to suffer from occupational contact dermatitis (Sarfiah et al, 2016). In addition, some workers had long nails and did not regularly cut their nails. Chemicals are easily attached to long nails which are not routinely cut. Long nails can also cause skin blisters caused by friction with the skin, making it easier for chemicals to enter the skin layers. Observations also found that many workers did not use hand washing soap. Chemicals are considered to be still attached to the exposed skin of workers' hands if the worker does not use hand washing soap when washing his hands. Lack of employees' awareness of chemicals in the work process causes workers to not have good personal hygiene practices. Thus, many workers sufferred from contact dermatitis.

Prevention efforts undertaken to reduce contact dermatitis are by upgrading workers' consciousness of the importance of personal hygiene by providing knowledge to workers about the importance of personal hygiene to maintain the safety and health of workers as well as supervision so that workers are committed to implement the concept of personal hygiene. Several concepts of personal hygiene need to be carried out so that metal coating industry workers can avoid contact dermatitis. This can be done by washing hand using water and soap before and after working, washing work clothes or changing work clothes every day, bathing regularly before and after work and cutting nails regularly to maintain personal hygiene.

\section{CONCLUSION}

Contact dermatitis can be caused by endogenous factors including age, working period, history of disease, and personal hygiene. According to the outcome of research conducted in the electroplating home industry in Durungbanjar Village, most of the workers experienced contact dermatitis. There is a strong relationship between personal hygiene and contact dermatitis case. Most of the workers experiencing contact dermatitis in the electroplating home industry in Durungbanjar Village have poor personal hygiene. Meanwhile, age, working period and history of disease show weak relationship with occupational contact dermatitis. In conclusion, personal hygiene is one of the factors causing contact dermatitis in electroplating workers in Durungbanjar Village.

\section{ACKNOWLEDGEMENTS}

The authors thank everyone who have contributed to the writing of this journal. The author also thanks the senior, Danang, who kindly helped the author finished this journal, the Faculty of Public Health, Universitas Airlangga, where the author studied. The last, the author would thank to journal review team who provided input to this journal and successfully sent it to the journal website.

\section{REFERENCES}

Alifariki, L. O., Kusnan, Adius and Saida (2019) 'Determinan Kejadian Dermatitis Kontak pada Pekerja Bengkel di Kota Kendari', Jurnal Keperawatan Muhammadiyah, 4(2), pp. 31-39.

Berniyanti, T. (2018) Biomarker Toksisitas: Paparan Logam Tingkat Molekuler. Surabaya: Pusat Penerbitan dan Percetakan Universitas Airlangga.

Chafidz, M. and Dwiyanti, E. (2018) 'Hubungan Lama Kontak, Jenis Pekerjaan dan Penggunaan APD dengan Kejadian Dermatitis Kontak pada Pekerja Tahu, Kediri', The Indonesian Journal of Occupational Safety and Health, 6(2), pp. 156-165.

Dhera, A. and Fielrantika, S. (2017) 'Hubungan Karakteristik Pekerja, Kelengkapan dan Higienitas APD dengan Kejadian Dermatitis Kontak (Studi Kasus di Rumah Kompos Jambangan Surabaya)', The Indonesian Journal of Occupational Safety and Health, 6(1), pp. 16-26. 
Djuanda, A. (2010) Ilmu Penyakit Kulit dan Kelamin. 6th edn. Jakarta: Balai Penerbit FKUI.

Ernasari (2012) Pengaruh Penyuluhan Dermatitis Kontak Terhadap Pengetahuan dan Sikap Perajin Tahu di Kelurahan Mabar Kecamatan Medan Deli Tahun 2011. Undergraduate Thesis. Medan: Faculty of Public Health, Universitas Sumatera Utara.

Fasya, A. H. Z. (2018) 'The Incidence of Dermatitis Analysis Based on Individual Characteristics of Metal Plating Workers in Sidoarjo', Jurnal Kesehatan Lingkungan, 10(2), pp. 149-158.

Fithri, N. K., Anggita, A. and Dewi, M. (2019) 'Pengaruh Kebiasaan Mencuci Tangan dengan Kejadian Dermatitis pada Pekerja Cleaning Service Jakarta Utara', Indonesian of Health Information Management Journal, 7(2), pp. 54-61.

Frosch, P.J., Kugler, K. (2011) 'Occupational contact dermatitis', in Contact Dermatitis. 5th edn. Heidelberg: Springer.

Hamzah, S. (2012) 'Factors that Corelation to The Incidence of Occupational Contact Dermatitis on the Workers of Car Washes in Sukarame Village Bandar Lampung City ', Faculty of Medicine Lampung University, ISSN 2337-, pp. 45-55.

Hastuty, M. (2018) 'Hubungan Personal Hygiene dengan Kejadian Dermatitis Kontak Iritan pada Pekerja di PT.Perindustrian dan Perdagangan Bangkinang Tahun 2016', Jurnal Ners, 2(2), pp. 11-17.

Hernita, S. (2011) Hubungan antara Kadar Interleukin-5 (Il-5) dalam Serum dengan Derajat Kepositifan Uji Tempel pada Penderita Dermatitis Kontak Nikel. Undergraduate Thesis. Medan: Faculty of Medical, Universitas Sumatera Utara.

International Labour Organization (2015) 'Global Trends on Occupational Accidents and Diseases', World Day for Safety and Health At Work, (April), pp. 1-7.

Lestari, F. and Utomo, H. S. (2007) 'Factors Associated with Contact Dermatitis on Workers at PT Inti Pantja Core Press Industri. (Faktor-Faktor Yang Berhubungan dengan Dermatitis Kontak Pada Pekerja Di PT Inti Pantja Press Industri).', Jurnal Makara Kesehatan, 11(2), pp. 61-68.

Marks, J. G. and Miller, J. J. (2017) Lookingbill and Marks' Principles of Dermatology. 6th edn. USA: Elsevier.

Miaratiska, N. and Azizah, R. (2015) 'Hubungan Paparan Nikel dengan Gangguan Kesehatan Kulit pada Pekerja Industri Rumah Tangga Pelapisan Logam di Kabupaten Sidoarjo', Perspektif Jurnal Kesehatan Lingkungan, 1(72), pp. 25-36.

Murlistyarini, S. and Prawitasari, S. (2018) Intisari Ilmu Kesehatan Kulit dan Kelamin. Malang: UB Press.

Paendong, R., Pandaleke, H. and Mawu, F. (2017) 'Gambaran Kejadian Dermatitis Kontak Akibat Kerja pada Petugas Cleaning Service di RSUP Prof. Dr. R. D. Kandou Manado', e-CliniC, 5(2), pp. 156-162.

Pradananingrum, S., Lestantyo, D. and Jayanti, S. (2018) 'Hubungan Personal Hygiene, Lama Kontak, dan Masa Kerja dengan Gejala Dermatitis Kontak Iritan pada Pengrajin Tahu Mrican Semarang', Jurnal Kesehatan Masyarakat, 6(4), pp. 378-386.

Prasetyo, D. A. (2014) Faktor-Faktor yang Berhubungan dengan Kejadian Dermatitis Kontak Iritan pada Tangan Pekerja Konstruksi yang Terpapar Semen di PT. Wijaya Kusuma Contractors Tahun 2014. Undergraduate Thesis. Jakarta: Faculty of Medical and Health Science, Universitas Islam Negeri Syarif Hidayatullah.

Putri, I. P. S. (2019) Faktor yang Berhubungan dengan Kejadian Dermatitis Kontak pada Petani Tembakau di Desa Ambulu Kecamatan Ambulu Kabupaten Jember. Undergraduate Thesis. Surabaya: Faculty of Public Health, Universitas Airlangga.

Putri, S., Nirmala, F. and Akifah, A. (2017) 'FaktorFaktor yang Berhubungan dengan Gejala Dermatitis Kontak pada Pekerja Bengkel Motor di Wilayah Kota Kendari Tahun 2016', Jurnal Ilmiah Mahasiswa Kesehatan Masyarakat Unsyiah, 2(6), pp. 1-8.

Rachmasari, N. (2012) 'Faktor-Faktor yang Berhubungan dengan Kejadian Dermatitis Kontak Iritan pada Pengrajin Logam di Desa Cepogo, Kecamatan Cepogo Kabupaten Boyolali', Jurnal Kesehatan Masyarakat Universitas Diponegoro, 2(1), pp. 1-10.

Rahma, G. A., Setyaningsih, Y. and Jayanti, S. (2017) 'Analisis Hubungan Faktor Eksogen dan Endogen Terhadap Kejadian Dermatitis Akibat Kerja pada Pekerja Penyamakan Kulit PT. Adi Satria Abadi Piyungan, Bantul', Jurnal Kesehatan Masyarakat (e-Journal), 5(5), pp. 173-183.

Rinawati, S. and Wulandari, S. M. (2020) 'The Related of Personal Hygiene and Contact Frequency with Contact Dermatitis Complaints in Motorbike Washing Workers in Jebres and 
Mojosongo Surakarta Districts', Journal of Vocational Health Studies, 3(3), pp. 109-113.

Rosanti, E., Rudyarti, E. and Diwa, M. A. P. S. (2018) 'the Correlation of Chemical Exposure and Personal Hygiene With Irritant Contact Dermatitis Among Workers in the Production Worker', Journal Of Vocational Health Studies, 2(1), pp. 8-13.

Sarfiah, Asfian, P. and Ardiansyah, R. T. (2016) 'Faktor-Faktor yang Berhubungan dengan Dermatitis Kontak Iritan pada Nelayan di Desalamanggau Kecamatan Tomia Kabupaten Wakatobi Tahun 2016', Jurnal Ilmiah Mahasiswa Kesehatan Masyarakat Unsyiah (JIMKESMAS), 1(3), pp. 1-9.

Soedirman; and Suma'mur (2014) Kesehatan Kerja dalam Perspektif Hiperkes \& Keselamatan Kerja. Jakarta: Erlangga.

Stateschu, L. (2011) Spitalul cCinic de Urgenta Clinic Dermatologie. Dutch: Universtatea de Medicina si Farmacie.
Suma'mur, P. . (2014) Kesehatan Kerja dalam Perspektif Hiperkes dan Keselamatan Kerja. Jakarta: PT. Gunung Agung.

Suryani (2011) Faktor yang Berhubungan dengan Dermatitis Kontak pada Pekerja Bagian Processing dan Filling PT. Cosmas Indonesia Tangerang Selatan Tahun 2011. Undergraduate Thesis. Jakarta: Faculty of Medical and Health Science, Universitas Islam Negeri Syarif Hidayatullah.

Wardani, H. K., Mashoedojo, M. and Bustamam, N. (2018) 'Faktor yang Berhubungan dengan Dermatitis Kontak Akibat Kerja pada Pekerja Proyek Bandara', The Indonesian Journal of Occupational Safety and Health, 7(2), pp. 249259 ..

Widianingsih, K. and Basri, S. (2017) 'Kejadian Dermatitis Kontak pada Pemulung di Tempat Pemrosesan Akhir (TPA) Pecuk Indramayu', Jurnal Kesehatan Masyarakat, 2(2), pp. 45-52. 